\title{
Utilization of zein-based coatings containing vegetable oils on the physicochemical characteristics of vacuum-packaged lamb meat
}

\author{
Cecília de Souza Cordeiro $^{1^{*}(\mathbb{D})}$ Lucimara Aparecida Forato $^{2}$ (D) Rubens Bernardes Filho ${ }^{2}$ (D) \\ Renata Tieko Nassu $^{3}$ (iD
}

${ }^{1}$ Faculdade de Ciências Farmacêuticas, Universidade Estadual Paulista (UNESP), 14800-903, Araraquara, SP, Brasil. E-mail: ceciliaengalimentos@gmail.com. *Corresponding author.

${ }^{2}$ Embrapa Instrumentação, São Carlos, SP, Brasil.

${ }^{3}$ Embrapa Pecuária Sudeste, São Carlos, SP, Brasil.

ABSTRACT: During the shelf-life of fresh meat, physical, chemical, microbiological, and sensory changes may occur. To avoid such changes, the combination of vacuum-packaging and use of edible coatings make a good strategy. This study aimed to evaluate the physicochemical characteristics of vacuum-packaged lamb meat combined with different zein-based edible coatings containing different vegetable oils (pink pepper, rosemary, olive oil, and the combinations of olive oil + pink pepper or rosemary), stored at $5 \pm 1{ }^{\circ} \mathrm{C}$. Parameters including $\mathrm{pH}$, instrumental color, water holding capacity (WHC), shear force, and thiobarbituric acid reactive substances (TBARS) were analyzed every seven days, for 29 days. Significant differences $(P<0.05)$ were observed in coating effects and storage time. The combination of olive oil and pepper oil (OLPP) exhibited higher color stability, while the coatings containing rosemary (RO), rosemary and olive oil (OLRO), and pink pepper oil (PP) exhibited the highest oxidative stability in 29 days. The pH, WHC, and shear force parameters did not appear to have been affected by the coatings. In summary, as appearance is an important purchasing factor, the coating containing olive oil and pink pepper oil is very promising as an alternative for maintaining vacuum-packaged lamb meat quality.

Key words: packaging, plasticizers, stability.

Utilização de revestimentos à base de zeínas contendo óleos vegetais sobre as características físico-químicas da carne de cordeiro embalada a vácuo

RESUMO: Durante a vida de prateleira da carne fresca podem ocorrer mudanças físico-químicas, microbiológicas e sensoriais indesejadas. Para evitar tais mudanças a combinação da embalagem tradicional à vácuo com revestimentos comestiveis é uma alternativa. O objetivo deste estudo foi avaliar o efeito do uso de diferentes revestimentos comestiveis à base de zeínas em combinação com diferentes óleos vegetais (óleos de: pimenta rosa, alecrim, azeite e combinação de azeite + óleo de pimenta rosa ou alecrim) nas características fisico-químicas da carne ovina, embalada à vácuo e armazenada à temperatura $5 \pm 1{ }^{\circ} \mathrm{C}$. Foram realizadas análises de pH, cor instrumental, capacidade de retenção de água (CRA), força de cisalhamento, substâncias reativas ao ácido tiobarbitúrico (TBARS) a cada sete dias, no período de 29 dias. Foram observadas diferenças significativas $(P<0,05)$ para o efeito de revestimentos e o tempo de armazenamento. A combinação de azeite mais óleo de pimenta (OLPP), apresentou maior estabilidade de cor, enquanto que os revestimentos contendo alecrim (RO), alecrim mais azeite (OLRO) e óleo de pimenta (PP) foram os que apresentaram maior estabilidade oxidativa no período de 29 dias. Os parâmetros pH, CRA e força de cisalhamento não parecem ter sido afetados pelos revestimentos. Tendo em vista que aparência é um importante fator de compra, o revestimento contendo azeite e óleo de pimenta rosa foi o mais promissor para ser utilizado na manutenção da qualidade de carne ovina. Palavras-chave: embalagem, estabilidade, plastificantes.

\section{INTRODUCTION}

In the Brazilian market, ovine meat production has gained importance as a growing activity (SNA, 2015). However, lamb meat consumption remains limited in comparison with other types of animal products.

The appearance of fresh meat directly affects the purchase and consumption of a product.
An extended shelf life helps reach farther markets, diminish financial losses, and meet demands for longer periods. Thus, the packaging is an important factor, as it could affect the quality and durability of fresh meat as well as modify the environment of the product, thereby delaying deteriorative reactions (ANDRADE, 2016; CARDOSO, 2016). This phenomenon depends on the product's characteristics and can be measured by microbiological, physicochemical, and sensory 
analyses. A strategy used for increasing the shelf life of meats is the use of edible coatings. Indeed, chitosan- and gelatin-based films have been used for color preservation and to inhibit lipid oxidation in beef. The best results were obtained with $3 \%$ and $6 \%$ gelatin, along with $0.5 \%$ and $1.0 \%$ of chitosan, and $6 \%$ glycerol (CARDOSO, 2016). In pork meat, chitosan coating has previously been used to inhibit deteriorative microorganisms. In one study, it was concluded that the addition of $0.3 \%$ and $0.6 \%$ of chitosan to the ground pork meat reduced the total microorganisms count of yeasts, molds, and lactic acid bacteria up to $3 \log \mathrm{FCU}_{\mathrm{g}}{ }^{-1}$ for 18 days at $4{ }^{\circ} \mathrm{C}$ (SAGOO, 2002). PETROU et al. (2012) used chitosan, oregano oil, and a combination of both in modified atmosphere extending the shelf life of chicken breast. Based on sensory data, the authors demonstrated a six-day extended shelf life with treatment combining chitosan and modified atmosphere and oregano oil and modified atmosphere, while the combination of chitosan, modified atmosphere, and oregano oil demonstrated up to 14 days extension.

Zeins, which are corn proteins from endosperm grain, are another alternative that can be used as an edible coating in meat. This product is obtained from the byproduct of the humid grounding of corn gluten. Zeins are considered high degree polymerization products and show isolating properties. Consequently, they are being applied in the production of coating for highly perishable food substances and microcapsules for the pharmaceutical industry FORATO et al., 2013). Generally, zein based films show a good barrier to oxygen, carbon dioxide, and other volatile compounds (HERNANDEZMUÑOZ, 2004). The zeins may show fragile and low flexibility films, suggestive of poor mechanical properties, mainly with humidity and temperature (FORATO et al., 2013). Plasticizers, which are organic compounds combined with polymeric materials, with high fusion point and low volatility, can be added to improve its properties (VIECELLI, 2011). Plasticizers are important in the formation of films and coatings because, when they are added to another material, they can change their physical and mechanical properties (BANKER, 1966). Vegetable oils can be added to coatings, thus acting as emulsifiers and plasticizers, increasing the films' flexibility and minimizing the high-water permeability (GARCÍA et al., 2000).

Nevertheless, studies involving the application of edible coatings in lamb meat and its effect in the product are scarce. This study aimed to study the effect of zein-based coatings, added to different vegetable oils as plasticizers, on the physicochemical characteristics of lamb meat.

\section{MATERIALS AND METHODS}

The meat samples used were obtained from the longissimus thoracis + lumborum muscles from intact males, same genetic group and diet, and slaughtered approximately at the same age and raised at Embrapa Pecuária Sudeste (São Carlos, SP, Brazil). Animals were weaned at 90 days and maintained in paddocks with supplementation of corn silage, mineral salt, and water up to 210 days when they were slaughtered. Carcasses were identified and stored in a cold chamber for $24 \mathrm{~h}$. Samples were taken to the Meat Analysis Laboratory from Embrapa Pecuaria Sudeste (São Carlos, SP, Brazil), where they were deboned. The longissimus thoracis + lumborum muscle was separated and cut into 2.5-cm-wide steaks. Seven different filmogenic solutions containing $4 \% \mathrm{w} / \mathrm{w}$ of zeins with different vegetable oils at the following concentrations: pink pepper (Schinnus terebinthifollus) oil - PP (Mundo dos Óleos, Brasilia, DF, Brazil), 0.5\% w/w; rosemary oil (Rosmarinus officinalis) - RO (Mundo dos Óleos, Brasilia, DF, Brazil), 0.5\% w/w; olive oil - OL (extra virgin oil, Gallo ${ }^{\circledR}$, Abrantes, Portugal), $1 \% \mathrm{w} / \mathrm{w}$; the combinations of olive oil $(0.5 \% \mathrm{w} / \mathrm{w})+$ pink pepper oil $(0.5 \% \mathrm{w} / \mathrm{w})$ - OLPP; and olive oil $(0.5 \% \mathrm{w} / \mathrm{w})$ + rosemary oil $(0.5 \% \mathrm{w} / \mathrm{w})$ - OLRO. They were solubilized in $70 \%$ ethanol, 0.87 density. Mixtures were homogenized in a beaker with a magnetic agitator at the temperature of $50{ }^{\circ} \mathrm{C}$ during $2 \mathrm{~h}$.

For the coating application in the lamb meat, the immersion in the filmogenic solution technique (dipping) was done according to CARDOSO et al. (2016). Steaks were immersed for $5 \mathrm{~s}$ in the filmogenic solution and kept in grids for thirty minutes in a low oxygen demand chamber at 4-6 ${ }^{\circ} \mathrm{C}$ to dry partially and to become with a homogeneous covering. After that, samples were vacuum-packaged in appropriate plastic bags (ZPP Embalagens Plásticas Ltda) in a vacuum packer (Selovac, model 300B, Sao Paulo, Brazil). The following analyses were performed on the samples every seven days, for 29 days: $\mathrm{pH}$, instrumental color, water holding capacity, shear force, and lipid oxidation. For instrumental color, steaks were exposed to atmospheric oxygen for $30 \mathrm{~min}$ before the

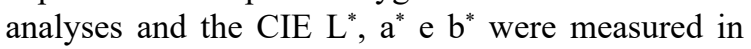
three different locations, using a colorimeter (Hunter Lab MiniScan XE, Hunter Associates Laboratory, Inc., Reston, VA, EUA), with a Universal Software v. 
4.10, D65 illuminant, and a $10^{\circ}$ observer. With these measurements, $\Delta \mathrm{E}$ between the initial and final days was calculated, according to the following formula: $\Delta \mathrm{E}=\left[\left(\Delta \mathrm{L}^{*}\right) 2+\left(\Delta \mathrm{a}^{*}\right) 2+\left(\Delta \mathrm{b}^{*}\right) 2\right] 1 / 2($ AMSA, 2012). The $\mathrm{pH}$ was measured in five points of the steaks, using a pH measuring instrument (Testo AG, model 230, Lenzkirch, Germany). The water holding capacity (WHC) was obtained by the difference between the weights of an approximately $2 \mathrm{~g}$ meat piece before and after being submitted to a $10 \mathrm{kgf}$ pressure for 5 min according to HAMM (1986), in triplicate.

For shear force (SF) measurements, the 2 $\mathrm{cm}$ thickness steaks were cooked in a TC 06 electric oven (Tedesco, Caxias do Sul, RS, Brazil), at 170 ${ }^{\circ} \mathrm{C}$ until the center of the sample reached $70{ }^{\circ} \mathrm{C}$, monitored by thermocouples linked to the FE-MUX software (Flyever, São Carlos, SP, Brasil). Samples were then cooled at room temperature and taken to a refrigerator at $5{ }^{\circ} \mathrm{C}$ for $24 \mathrm{~h}$. Three to four $1 \mathrm{~cm}$ side subsamples were removed parallel to the fiber grain. The maximum peak shear force was determined in each piece perpendicular to the fiber grain, using a $1.016 \mathrm{~mm}$ Warner Bratzler probe in TA.XT Plus Texture Analyzer (200 mm. min ${ }^{-1}$ crosshead speed, 50 $\mathrm{kg}$ load cell, $40 \mathrm{~mm}$ distance, and $10 \mathrm{~kg}$ calibration weight Stable Micro Systems Ltd., Surrey, UK). Maximum peak values were divided by the area to obtain the final result, which was averaged for nine to twelve subsamples.

The thiobarbituric acid reactive substances (TBARS) analysis was done to describe the lipid oxidation extension in the meat samples, using trichloride acid (TCA) and 2- thiobarbituric acid (TBA), with modifications in the method described by VYNCKE (1970; 1975), using thiobarbituric acid at a concentration of $0.04 \mathrm{M}$. Analyses were performed in triplicate. Results were reported in $\mathrm{mg}$ malonaldehyde/ $\mathrm{kg}$ of meat sample.

The obtained data were analyzed by analysis of variance (ANOVA), with the type of coatings and time as fixed factors and its interactions. When significant differences were reported $(\mathrm{P}<0.05)$, the Student-Newman-Keuls (SNK) was applied, considered the adequate test for the type of data obtained.

\section{RESULTS AND DISCUSSION}

There was no significant difference $(\mathrm{P}>0.05)$ in the instrumental (objective) color parameters $L^{*}, a^{*}$, and $b^{*}$ (Table 1) among the different coatings, except for the initial times for $L^{*}$ and $b^{*}$, where the control sample showed lower values compared to the others and in the $22^{\text {nd }}$ day for $\mathrm{a}^{*}$ parameter. For time, RO, OL, and OLPP showed significant differences $(\mathrm{P}<0.05)$ for $\mathrm{L}^{*}$; significant differences $(\mathrm{P}<0.05)$ for $\mathrm{a}^{*}$ in the RO, OLRO and PP treatments and $b^{*}$ parameter, only PP showed significant differences $(\mathrm{P}<0.05)$. To get a better understanding, if these differences were noticed for the human eye, the $\Delta \mathrm{E}$ values were calculated among the initial, intermediate, and final times (Table 1). When $\Delta \mathrm{E}$ value is lower than 2 , it means that there is no obvious difference noticeable by the human eye (MOKRZYCKI \& TATOL, 2011). Only the OLPP treatment showed this value between the initial and $22^{\text {nd }}$ days, meaning that if the difference is not noticeable between the initial and final times, the treatment was effective for maintaining the color by time. At 29 days, all the $\Delta \mathrm{E}$ values for all the treatments were higher than this limit value. In this same treatment, when instrumental color was observed by time, the sample showed higher values of $\mathrm{L}^{*}$ from day 8 , but did not affect the $\mathrm{a}^{*}$ and $\mathrm{b}^{*}$ parameters, thus maintaining the product color. This fact did not occur with the samples of the other treatments, which affected the $a^{*}$ parameter. The luminosity $\left(\mathrm{L}^{*}\right)$ is considered one of the most important parameters for meat products quality (GARCÍA-ESTEBAN, 2003). According to ZEOLA et al. (2007), the lower the luminosity $\left(\mathrm{L}^{*}\right)$ value, the darker is the meat. The $\mathrm{a}^{*}$ parameter, related to red color, is very important for the acceptability of fresh meat, as it is the main color parameter related to red meat (RAMOS \& GOMIDE, 2007). The meat with low $L^{*}$ and high $a^{*}$ values show redder color (SIMÕES \& RICARDO, 2000).

In table 2, the values for $\mathrm{pH}, \mathrm{WHC}, \mathrm{SF}$, and TBARS values are shown. For $\mathrm{pH}$ measurements, significant differences $(\mathrm{P}<0.05)$ were reported among the treatments from day 8 . Only RO treatment did not show a significant difference $(\mathrm{P}>0.05)$. Also, $\mathrm{pH}$ values were not different $(\mathrm{P}>0.05)$ comparing the initial and final days for the rest of the treatments (OL, OLRO, OLPP, and PP) or lower in the treatment CONT, as expected. The $\mathrm{pH}$ values ranged from 5.39 to 5.57 , close to those reported by SOBRINHO et al. (2005) and HOPKINS \& FOGARTY (1998), for lamb meat. For water holding capacity, there was no significant difference $(\mathrm{P}>0.05)$ among the treatments, except at 15 days, where the values ranged from $75.93 \%$ (CONT) to $83.88 \%$ (OL). However, this behavior was not observed in the other studied times. CONT and OLRO treatments showed a significant difference $(\mathrm{P}<0.05)$ with increasing values with time for WHC. The use of olive oil combined with rosemary may cause a higher barrier to water, leading to an increase 
Table 1 - Average values of instrumental color $\left(\mathrm{L}^{*}, \mathrm{a}^{*}, \mathrm{~b}^{*}\right)$ and $\Delta \mathrm{E}$ for lamb meat coated with different formulations based in zeins and vegetable oils stored at $4-6{ }^{\circ} \mathrm{C}$ for 36 days.

\begin{tabular}{|c|c|c|c|c|c|c|c|c|}
\hline Parameter & $\begin{array}{l}\text { Time } \\
\text { (days) }\end{array}$ & CONT & $\mathrm{OL}$ & PP & RO & OLPP & OLRO & $\mathrm{p}$ (trat) \\
\hline \multirow{5}{*}{$\mathrm{L}^{*}$} & 1 & $35.61 \pm 0.75^{b}$ & $35.37 \pm 0.53^{\mathrm{bC}}$ & $37.77 \pm 1.09^{\mathrm{a}}$ & $37.45 \pm 0.74^{\mathrm{aC}}$ & $36.83 \pm 1.02^{\mathrm{aB}}$ & $37.24 \pm 0.36^{\mathrm{a}}$ & 0.012 \\
\hline & 8 & $35.52 \pm 0.32^{\mathrm{d}}$ & $40.21 \pm 1.86^{\mathrm{aA}}$ & $37.77 \pm 1.33^{\mathrm{b}}$ & $38.01 \pm 0.61^{\mathrm{bBC}}$ & $38.80 \pm 0.65^{\mathrm{cA}}$ & $36.72 \pm 0.29^{c}$ & 0.002 \\
\hline & 15 & $37.23 \pm 1.37$ & $38.61 \pm 0.92^{\mathrm{B}}$ & $38.92 \pm 1.36$ & $38.83 \pm 0.70^{\mathrm{B}}$ & $38.36 \pm 0.92^{\mathrm{A}}$ & $39.56 \pm 1.97$ & 0.369 \\
\hline & 22 & $37.20 \pm 3.24$ & $38.75 \pm 0.91^{\mathrm{B}}$ & $38.36 \pm 0.73$ & $36.20 \pm 0.47^{\mathrm{D}}$ & $38.14 \pm 0.37^{\mathrm{A}}$ & $36.09 \pm 0.85$ & 0.188 \\
\hline & 29 & $39.19 \pm 1.85$ & $38.61 \pm 1.31^{\mathrm{B}}$ & $40.27 \pm 1.16$ & $42.24 \pm 2.23^{\mathrm{A}}$ & $38.34 \pm 0.54^{\mathrm{A}}$ & $39.34 \pm 2.97$ & 0.190 \\
\hline $\mathrm{P}$ (time) & & 0.164 & 0.007 & 0.117 & 0.001 & 0.029 & 0.091 & \\
\hline \multirow{5}{*}{$a^{*}$} & 1 & $14.16 \pm 1.35^{\mathrm{A}}$ & $15.07 \pm 1.43$ & $16.46 \pm 1.69^{\mathrm{A}}$ & $15.32 \pm 0.55^{\mathrm{A}}$ & $14.82 \pm 0.08$ & $16.28 \pm 0.49^{\mathrm{A}}$ & 0.164 \\
\hline & 8 & $14.44 \pm 0.44^{\mathrm{A}}$ & $14.87 \pm 0.43$ & $14.29 \pm 0.50^{\mathrm{B}}$ & $14.42 \pm 0.23^{\mathrm{B}}$ & $13.84 \pm 1.92$ & $15.71 \pm 0.31^{\mathrm{A}}$ & 0.222 \\
\hline & 15 & $14.64 \pm 0.77^{\mathrm{A}}$ & $13.14 \pm 1.43$ & $13.85 \pm 0.64^{\mathrm{B}}$ & $13.54 \pm 1.00^{\mathrm{C}}$ & $13.12 \pm 0.35$ & $15.29 \pm 0.52^{\mathrm{A}}$ & 0.052 \\
\hline & 22 & $11.85 \pm 1.13^{\mathrm{bB}}$ & $14.08 \pm 0.94^{\mathrm{a}}$ & $11.21 \pm 0.35^{\mathrm{bC}}$ & $13.66 \pm 0.96^{\mathrm{aC}}$ & $14.59 \pm 0.49^{\mathrm{a}}$ & $13.74 \pm 0.69^{\mathrm{aB}}$ & 0.001 \\
\hline & 29 & $10.91 \pm 1.02^{\mathrm{C}}$ & $12.46 \pm 1.08$ & $10.08 \pm 0.56^{\mathrm{D}}$ & $9.77 \pm 0.36^{\mathrm{D}}$ & $12.31 \pm 1.81$ & $12.07 \pm 1.81^{\mathrm{C}}$ & 0.075 \\
\hline $\mathrm{P}$ (time) & & 0.003 & 0.075 & $<0.0001$ & $<0.0001$ & 0.144 & 0.002 & \\
\hline \multirow{5}{*}{$b^{*}$} & 1 & $11.19 \pm 1.04^{\mathrm{e}}$ & $11.94 \pm 0.95^{\mathrm{d}}$ & $14.53 \pm 0.309^{\mathrm{aA}}$ & $13.77 \pm 0.13^{\mathrm{b}}$ & $12.92 \pm 0.35^{\mathrm{c}}$ & $13.30 \pm 0.91^{b c}$ & 0.001 \\
\hline & 8 & $11.44 \pm 0.39$ & $12.95 \pm 0.75$ & $11.67 \pm 0.44^{\mathrm{E}}$ & $12.51 \pm 0.74$ & $12.12 \pm 1.37$ & $12.85 \pm 0.12$ & 0.138 \\
\hline & 15 & $12.06 \pm 0.35$ & $13.53 \pm 0.66$ & $13.24 \pm 0.25^{\mathrm{B}}$ & $12.94 \pm 1.36$ & $13.64 \pm 0.23$ & $13.59 \pm 0.58$ & 0.112 \\
\hline & 22 & $11.97 \pm 0.27$ & $13.34 \pm 0.32$ & $12.65 \pm 0.48^{\mathrm{C}}$ & $12.85 \pm 0.50$ & $13.28 \pm 0.58$ & $12.37 \pm 1.59$ & 0.280 \\
\hline & 29 & $11.95 \pm 0.24$ & $13.03 \pm 0.42$ & $12.01 \pm 0.29^{\mathrm{D}}$ & $13.05 \pm 0.80$ & $13.16 \pm 0.95$ & $11.90 \pm 0.97$ & 0.093 \\
\hline $\mathrm{P}($ time $)$ & & 0.281 & 0.101 & $<0.0001$ & 0.459 & 0.284 & 0.269 & \\
\hline \multirow{4}{*}{$\Delta \mathrm{E}$} & $1 \times 8$ & 0.4 & 4.9 & 3.6 & 1.6 & 2.3 & 0.9 & \\
\hline & $1 \times 15$ & 1.9 & 4.1 & 3.1 & 2.4 & 2.4 & 2.5 & \\
\hline & $1 \times 22$ & 2.9 & 3.8 & 5.6 & 2.3 & 1.4 & 2.9 & \\
\hline & $1 \times 29$ & 4.9 & 4.3 & 7.3 & 7.4 & 2.9 & 4.9 & \\
\hline
\end{tabular}

a-c Means with different lowercase letters in the lines are significantly different $(\mathrm{p}<0.05)$ by SNK test; A-C Means with different uppercase letters in the columns are significantly different $(\mathrm{p}<0.05)$ by $\mathrm{SNK}$ test; $\mathrm{CONT}=$ control; $\mathrm{OL}=$ olive oil; $\mathrm{PP}=$ pink pepper oil; $\mathrm{RO}=$ rosemary oil; $\mathrm{OLPP}=$ olive + pink pepper oil; $\mathrm{OLRO}=$ olive + rosemary oil; trat $=$ treatment.

in this parameter; although, the same occurred in the CONT sample. The shear force showed significant values $(\mathrm{P}<0.05)$ among all the treatments in all studied times. The less the force to have the meat cut, the more tender is the beef cut (KOOHMARAIE, 2002; SANTOS, 2015). It is expected that the aging process directly affects the shear force, and it is associated with lowering values along time (MONSÓN et al., 2004), but it was not observed in this study. Only the CONT sample showed this behavior, while the other treatments presented the same values in the initial and final time of this study (RO, OL and PP treatments) or even an increase (OLRO treatment). It is important to note that all shear force obtained values were lower than $2.18 \mathrm{kgf}$, meaning that they were from very tender meat, compared to values reported in other studies, ranging between 4.46- $4.85 \mathrm{kgf}$ (ZAPATA, 2000) and 2.08-3.43 kgf (GULARTE et al., 2000) are reported. Edible coatings used in this study did not seem to affect the tenderness of lamb meat.
Myoglobin and lipid oxidation are closely related in meat (RENERRE \& LABADIE, 1993) and depend on the equilibrium of anti- and pro-oxidant substances, including the polyunsaturated fatty acids (PUFAs). Thus, the less the oxidation, the lower the modification in meat color will be. Values of TBARS (Thiobarbituric Acid Reactive Substances) higher than 1.0 malonaldehyde (MDA). $\mathrm{kg}^{-1}$ indicated that oxidation is noticeable by a sensory panel (LIMBO et al., 2010). In this study, it was observed that all average values by the time were lower than 0.2 mg.MDA. $\mathrm{kg}^{-1}$ of meat (Table 2 ), thus the samples were considered within an acceptable range. Lamb meat is less prone to lipid oxidation as it has a higher proportion of saturated fatty acids and lower of polyunsaturated fatty acids (SINCLAIR, 2007), which justifies the low values for lipid oxidation. Except for one day time, significant differences $(\mathrm{P}<0.05)$ were found among treatments in all the studied times. As expected, in 
Table 2 - Average values of meat quality analyses for lamb meat coated with different formulations based in zeins and vegetable oils stored at $4-6^{\circ} \mathrm{C}$ for 36 days.

\begin{tabular}{|c|c|c|c|c|c|c|c|c|}
\hline Parameter & $\begin{array}{l}\text { Time } \\
\text { (days) }\end{array}$ & CONT & $\mathrm{OL}$ & PP & RO & OLPP & OLRO & $\mathrm{p}$ (trat) \\
\hline \multirow{5}{*}{$\mathrm{p}$} & 1 & $5.51 \pm 0.02^{\mathrm{B}}$ & $5.49 \pm 0.02^{\mathrm{B}}$ & $5.47 \pm 0.01^{\mathrm{BC}}$ & $5.47 \pm 0.02$ & $5.48 \pm 0.04^{\mathrm{A}}$ & $5.48 \pm 0.05^{\mathrm{A}}$ & 0.246 \\
\hline & 8 & $5.55 \pm 0.02^{\mathrm{aA}}$ & $5.51 \pm 0.01^{\mathrm{cA}}$ & $5.53 \pm 0.03^{\mathrm{bA}}$ & $5.45 \pm 0.01^{\mathrm{e}}$ & $5.50 \pm 0.01^{\mathrm{dA}}$ & $5.49 \pm 0.01^{\mathrm{dA}}$ & $<0.0001$ \\
\hline & 15 & $5.51 \pm 0.03^{\mathrm{B}}$ & $5.51 \pm 0.02^{\mathrm{A}}$ & $5.49 \pm 0.02^{\mathrm{B}}$ & $5.46 \pm 0.01$ & $5.44 \pm 0.01^{\mathrm{B}}$ & $5.45 \pm 0.01^{\mathrm{BC}}$ & $<0.0001$ \\
\hline & 22 & $5.48 \pm 0.03^{\mathrm{aC}}$ & $5.39 \pm 0.02^{\mathrm{cC}}$ & $5.48 \pm 0.03^{\mathrm{aB}}$ & $5.47 \pm 0.03^{\mathrm{a}}$ & $5.37 \pm 0.01^{\mathrm{cC}}$ & $5.44 \pm 0.03^{\mathrm{bC}}$ & $<0.0001$ \\
\hline & 29 & $5.48 \pm 0.03^{\mathrm{aC}}$ & $5.48 \pm 0.03^{\mathrm{aB}}$ & $5.44 \pm 0.03^{\mathrm{bC}}$ & $5.43 \pm 0.03^{\mathrm{b}}$ & $5.50 \pm 0.01^{\mathrm{aA}}$ & $5.47 \pm 0.02^{\mathrm{aAB}}$ & 0.004 \\
\hline $\mathrm{P}($ time $)$ & & 0.002 & $<0.0001$ & 0.001 & 0.124 & $<0.0001$ & 0.030 & \\
\hline \multirow{5}{*}{ WHC (\%) } & 1 & $76.52 \pm 1.85^{\mathrm{C}}$ & $78.48 \pm 2.92$ & $77.86 \pm 3.67$ & $78.39 \pm 2.97$ & $77.28 \pm 1.26$ & $73.75 \pm 0.57^{\mathrm{C}}$ & 0.244 \\
\hline & 8 & $79.55 \pm 0.34^{\mathrm{B}}$ & $80.97 \pm 2.81$ & $82.70 \pm 1.13$ & $80.84 \pm 3.51$ & $83.14 \pm 3.20$ & $80.69 \pm 2.68^{A}$ & 0.549 \\
\hline & 15 & $75.93 \pm 1.62^{\mathrm{dC}}$ & $83.88 \pm 2.80^{\mathrm{a}}$ & $81.65 \pm 3.45^{\mathrm{b}}$ & $80.10 \pm 3.19^{\mathrm{bc}}$ & $78.30 \pm 0.06^{\mathrm{c}}$ & $78.58 \pm 1.01^{\mathrm{cB}}$ & 0.020 \\
\hline & 22 & $79.79 \pm 1.84^{\mathrm{B}}$ & $81.00 \pm 1.34$ & $82.18 \pm 2.60$ & $80.45 \pm 1.87$ & $80.36 \pm 2.45$ & $78.37 \pm 0.78^{\mathrm{B}}$ & 0.324 \\
\hline & 29 & $82.95 \pm 1.39^{\mathrm{A}}$ & $82.01 \pm 1.74$ & $83.45 \pm 0.99$ & $81.55 \pm 1.42$ & $80.17 \pm 3.15$ & $81.10 \pm 3.09^{\mathrm{A}}$ & 0.482 \\
\hline $\mathrm{P}($ time $)$ & & 0.001 & 0.175 & 0.161 & 0.695 & 0.090 & 0.006 & \\
\hline \multirow{5}{*}{$\mathrm{SF}\left(\mathrm{kgfcm}^{-1}\right)$} & 1 & $2.01 \pm 0.41^{\mathrm{aA}}$ & $1.71 \pm 0.26^{\mathrm{b}}$ & $1.53 \pm 0.50^{\mathrm{bB}}$ & $1.35 \pm 0.19^{\mathrm{bC}}$ & $1.42 \pm 0.33^{\mathrm{bAB}}$ & $1.35 \pm 0.22^{\mathrm{bB}}$ & 0.001 \\
\hline & 8 & $1.76 \pm 0.36^{\mathrm{aA}}$ & $1.65 \pm 0.36^{\mathrm{ab}}$ & $1.68 \pm 0.43^{\mathrm{abB}}$ & $2.02 \pm 0.36^{\mathrm{aA}}$ & $1.29 \pm 0.23^{\mathrm{cAB}}$ & $1.39 \pm 0.23^{\mathrm{bcB}}$ & $<0.0001$ \\
\hline & 15 & $1.25 \pm 0.28^{\mathrm{cB}}$ & $1.82 \pm 0.30^{\mathrm{b}}$ & $2.18 \pm 0.42^{\mathrm{aA}}$ & $1.87 \pm 0.35^{\mathrm{bAB}}$ & $1.56 \pm 0.24^{\mathrm{bA}}$ & $1.68 \pm 0.36^{\mathrm{bA}}$ & $<0.0001$ \\
\hline & 22 & $1.92 \pm 0.41^{\mathrm{aA}}$ & $1.84 \pm 0.29^{\mathrm{a}}$ & $1.77 \pm 0.47^{\mathrm{aB}}$ & $1.54 \pm 0.23^{\mathrm{abC}}$ & $1.30 \pm 0.28^{\mathrm{bAB}}$ & $1.82 \pm 0.28^{\mathrm{aA}}$ & 0.001 \\
\hline & 29 & $1.46 \pm 0.31^{\mathrm{aB}}$ & $1.54 \pm 0.17^{\mathrm{a}}$ & $1.67 \pm 0.25^{\mathrm{aB}}$ & $1.65 \pm 0.35^{\mathrm{aC}}$ & $1.15 \pm 0.30^{\mathrm{bB}}$ & $1.70 \pm 0.19^{\mathrm{aA}}$ & $<0.0001$ \\
\hline $\mathrm{P}($ time $)$ & & $<0.0001$ & 0.115 & 0.007 & $<0.0001$ & 0.011 & $<0.0001$ & \\
\hline \multirow{5}{*}{$\begin{array}{l}\text { TBARS } \\
\left(\mathrm{mg} \mathrm{MDA} \mathrm{kg}^{-1}\right)\end{array}$} & 1 & $0.057 \pm 0.008^{\mathrm{D}}$ & $0.057 \pm 0.004^{\mathrm{D}}$ & $0.051 \pm 0.013^{\mathrm{C}}$ & $0.048 \pm 0.012^{\mathrm{D}}$ & $0.060 \pm 0.007^{\mathrm{C}}$ & $0.059 \pm 0.004^{\mathrm{D}}$ & 0.504 \\
\hline & 8 & $0.079 \pm 0.008^{\mathrm{bB}}$ & $0.120 \pm 0.007^{\mathrm{aB}}$ & $0.067 \pm 0.007^{\mathrm{dB}}$ & $0.071 \pm 0.009^{\mathrm{cC}}$ & $0.061 \pm 0.009^{\mathrm{dC}}$ & $0.082 \pm 0.007^{\mathrm{bC}}$ & $<0.0001$ \\
\hline & 15 & $0.060 \pm 0.014^{\mathrm{aCD}}$ & $0.088 \pm 0.005^{\mathrm{aC}}$ & $0.072 \pm 0.003^{\mathrm{cdB}}$ & $0.040 \pm 0.002^{\mathrm{dD}}$ & $0.038 \pm 0.003^{\mathrm{bD}}$ & $0.064 \pm 0.007^{\mathrm{cD}}$ & $<0.0001$ \\
\hline & 22 & $0.068 \pm 0.003^{\mathrm{dC}}$ & $0.085 \pm 0.003^{\mathrm{cC}}$ & $0.115 \pm 0.009^{\mathrm{bA}}$ & $0.086 \pm 0.008^{\mathrm{cB}}$ & $0.127 \pm 0.005^{\mathrm{aB}}$ & $0.115 \pm 0.005^{\mathrm{bB}}$ & $<0.0001$ \\
\hline & 29 & $0.178 \pm 0.003^{\mathrm{aA}}$ & $0.184 \pm 0.010^{\mathrm{aA}}$ & $0.114 \pm 0.010^{\mathrm{cdA}}$ & $0.099 \pm 0.018^{\mathrm{dA}}$ & $0.153 \pm 0.029^{\mathrm{bA}}$ & $0.128 \pm 0.024^{\mathrm{cA}}$ & 0.001 \\
\hline $\mathrm{P}$ (time) & & $<0.0001$ & $<0.0001$ & $<0.0001$ & 0.001 & $<0.0001$ & $<0.0001$ & \\
\hline
\end{tabular}

${ }^{\mathrm{a}-\mathrm{c}}$ Means with different lowercase letters in the lines are significantly different $(\mathrm{p}<0.05)$ by SNK test; ${ }^{\text {A-C }}$ Means with different uppercase letters in the columns are significantly different $(\mathrm{p}<0.05)$ by $\mathrm{SNK}$ test; $\mathrm{CONT}=$ control; $\mathrm{OL}=$ olive oil; $\mathrm{PP}=\mathrm{pink}$ pepper oil; $\mathrm{RO}=$ rosemary oil; $\mathrm{OLPP}=$ olive + pink pepper oil; $\mathrm{OLRO}=$ olive + rosemary oil; trat $=$ treatment; TBARS $=$ Reactive Substances to Thiobarbituric Acid; MDA = malonaldehyde.

the 29 days, the CONT treatment showed the highest value for lipid oxidation, accompanied by OL treatment (0.178 mg.MDA. $\mathrm{kg}^{-1}$ and 0.184 mg.MDA. $\mathrm{kg}^{-1}$, respectively). The RO treatment was the one which showed the lowest value of lipid oxidation. Among the essential oils, the major number or reports about antioxidant properties are from plant extracts from the Labiatae family, particularly rosemary (WASZKOWIAK, 2008). According to VIUDA-MARTOS et al. (2010), the rosemary oils components can create the $\mathrm{Fe}^{2+}$, catalyzing the interaction and decomposition of hydroperoxides. ULIANA et al. (2016), when evaluating pink pepper leaves by the maceration method, reported a high concentration of total phenolic compounds and strong antioxidant activity. Therefore, the low lipid oxidation values noted in the present study, for the
RO, OLRO, and PP treatments are consistent with the added vegetable oils in the zein filmogenic solutions. By the time, TBARS values increased as expected, with significant differences $(\mathrm{P}<0.05)$ reported for all treatments. Figure 1 shows the principal component analysis (PCA) biplot, where the relationship between treatments combined to times and their physicochemical could be seen. It could be observed that samples at 1 day, at the right side of the graph, tended to be close to the $\mathrm{a}^{*}$ parameter, meaning that they were redder at this initial time. As time went by, there were modifications on $\mathrm{L}^{*}$, TBARS, and WHC, which were observable at 22 and 29 days, independently of the treatment, on the left side of the graph. As the two coordinates explained only $60 \%$ of the variation among the samples, it was not possible to conclude only based on this analysis, 


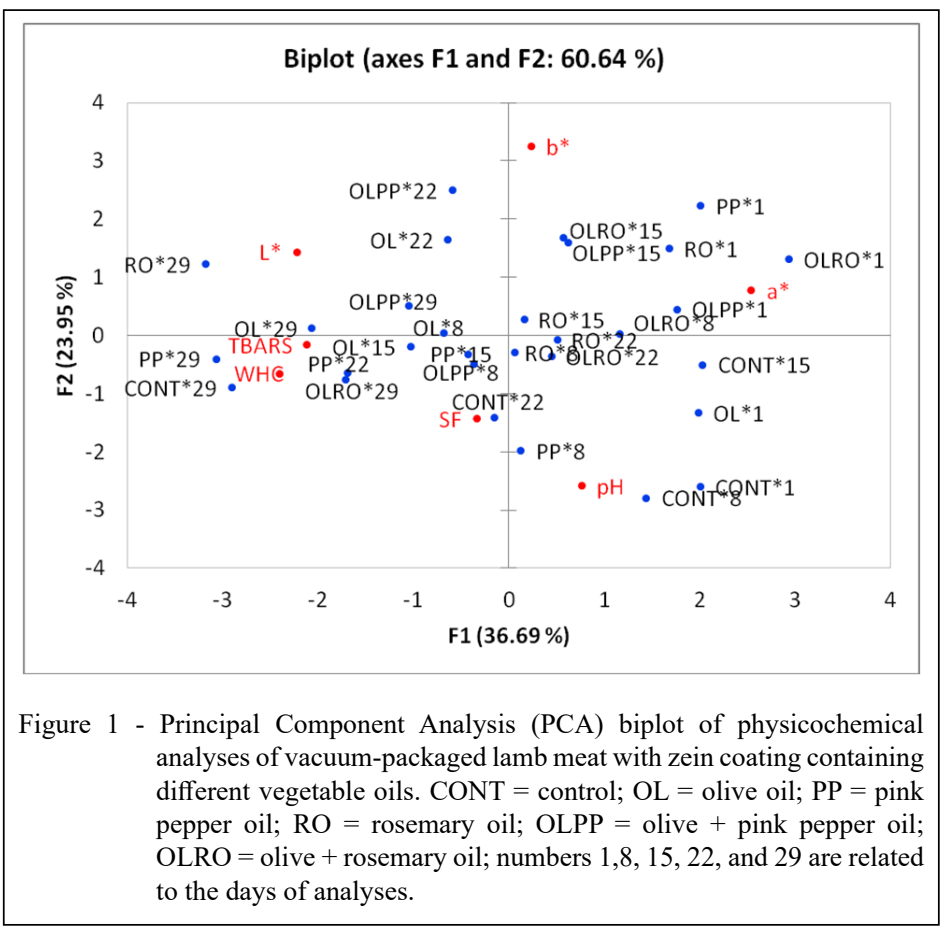

which was the best combination, but it gave us an idea about the behavior of the treatments, by time.

\section{CONCLUSION}

Vacuum-packaged lamb meat with zein coating, containing the combination of olive oil and pink pepper oil showed the higher color stability, while zein coatings containing rosemary alone or combined with olive oil and even pink pepper alone, showed the highest oxidative stability in 29 days; although, all the treatments showed values below the threshold perceived by humans. The parameters, including $\mathrm{pH}$, WHC, and shear force, did not seem to be affected by the coatings. Thus, as appearance is the most important attribute for purchasing decisions made by the consumer, the combination of olive oil and pink pepper would be the most promising alternative for food coating.

\section{ACKNOWLEDGMENTS}

The authors thank Fundação de Amparo à Pesquisa do Estado de São Paulo (FAPESP) (process 2016/18232-3) for financial support for this project, Embrapa Pecuária Sudeste, Embrapa Instrumentação, Conselho Nacional de Desenvolvimento Científico e Tecnológico $(\mathrm{CNPq})$ for the M.Sc. scholarship for Cecília Souza Cordeiro (process 134357/2016-7) and AgroNano network. And this study was financed in part by the Coordenação de Aperfeiçoamento de Pessoal de Nível Superior (CAPES), Brasil - Finance code 001.

\section{DECLARATION OF CONFLICT OF INTERESTS}

The authors declare no conflict of interests. The founding sponsors had no role in the design of the study; in the collection, analyses, or interpretation of data; in the writing of the manuscript; and in the decision to publish the results.

\section{AUTHOR'S CONTRIBUTIONS}

All authors contributed equally to this manuscript.

\section{REFERENCES}

ANDRADE, J.C. et al. Influence of evoked contexts on rating-based conjoint analysis: Case study with lamb meat, v.53, p.168-175, 2016. Available from: <https://doi.org/10.1016/j.foodqual.2016.06.013> Accessed: Aug. 19, 2019. doi: 10.1016/j.foodqual.2016.06.013.

AMSA, Meat color measurement guidelines, American Meat Science Association, 201 West Springfield Avenue, Suite 1202, Champaign, 136p, 2012. Available from: <https://meatscience. org/docs/default-source/publications-resources/Hot-Topics/ download-the-ebook-format-pdf-of-the-meat-color-measurementguidelines.pdf?sfvrsn=a218b8b30>. Accessed: Aug. 19, 2019.

BANKER, G.S. Film coating - theory and practice. Journal of Pharmaceutical Science, v.55, n.1, p.81-89, 1966. Available from: $<$ https://doi.org/10.1002/jps.2600550118>. Accessed: Aug. 15, 2018. doi: 10.1002/jps.2600550118.

CARDOSO, G.P. et al. Selection of a chitosan gelatinbased edible coating for color preservation of beef in retail 
display. Meat Science, v.114, p.85-94, 2016. Available from: $<$ https://doi.org/10.1016/j.meatsci.2015.12.012>. Accessed: Nov. 21, 2017. doi: 10.1016/j.meatsci.2015.12.012.

FORATO, L.A. et al. Mechanical and wetting properties of zein films extracted from corn gluten meal. Polímeros, v.23, n.1, p.42-48, 2013. Available from: <http://dx.doi.org/10.1590/S010414282012005000075>. Accessed: Aug. 15, 2018. doi: 10.1590/ S0104-14282012005000075.

GARCÍA-ESTEBAN, M. et al. Optimization of instrumental color analysis in dry-cured ham. Meat Science, v.63, n.3, p.287292, 2003. Available from: <https://doi.org/10.1016/S03091740(02)00084-0>. Accessed: Jan. 20, 2019. doi: 10.1016/S03091740(02)00084-0.

GARCÍA, M. et al. Lipid addition to improve barrier properties of edible starch-based films and coatings. Journal of Food Science, v.65, p.941-944, 2000. Available from: <https://doi. org/10.1111/j.1365-2621.2000.tb09397.x>. Accessed: Dec. 16, 2017. doi: $10.1111 / j .1365-2621.2000 . t b 09397 . x$.

GULARTE, M.A. et al. Meat lamb tenderness influenced by age and sex in corriedale lineage. Ciência Rural.; v.30, n.3, p.485488, 2000. Available from: <http://dx.doi.org/10.1590/S0103$84782000000300019>$. Accessed: Dec. 16, 2017. doi: 10.1590/ S0103-84782000000300019.

HAMM, R. Functional properties of the myofibrillar system and their measurement. In: Bechtel PJ. (Ed.). Muscle as food. New York: Academic Press. 1986; 135-199.

HERNANDEZ-MUÑOZ, P. et al. Effect of thermal treatments on functional properties of edible films made from wheat gluten fractions. Food Hydrocolloids, v.18, n.4, p.647654, 2004. Available from: <https://doi.org/10.1016/j. foodhyd.2003.11.002>. Accessed: Jun. 22, 2018. doi: 10.1016/j. foodhyd.2003.11.002.

HOPKINS, D.L.; FOGARTY, N.M. Diverse lamb genotypes - 2. Meat pH, colour, and tenderness. Meat Science, v.49, n.4 p.477-488, 1998. Available from: <https://doi.org/10.1016/S03091740(98)00051-5>. Accessed: Jun. 3, 2018. doi: 10.1016/S03091740(98)00051-5.

KOOHMARAIE, M. et al. Meat tenderness, and muscle growth: is there any relationship? Meat Science, v.22, n.62, p.345352, 2002. Available from: <https://doi.org/10.1016/S03091740(02)00127-4>. Accessed: Jun. 22, 2018. doi: 10.1016/ S0309-1740(02)00127-4.

LIMBO, S. et al. Evaluation and predictive modeling of shelf life of minced beef stored in high-oxygen modified atmosphere packaging at different temperatures. Meat Science, v.84, n.1, p.129-136, 2010. Available from: <https://doi.org/10.1016/j. meatsci.2009.08.035>. Accessed: Aug. 15, 2018. doi: 10.1016/j. meatsci.2009.08.035.

MOKRZYCKI, W.S.; TATOL, M. Color difference delta E-a survey. Machine Graphic \& Vision, v.20, n.4, p.383-411, 2011.

MONSÓN, F. et al. Influence of cattle breed and ageing time on textural meat quality. Meat Science, v.68, p.565602, 2004. Available from: <https://doi.org/10.1016/j. meatsci.2004.05.011>. Accessed: Aug. 15, 2018. doi: 10.1016/j. meatsci.2004.05.011.
PETROU, S. et al. Chitosan dipping or oregano oil treatments, singly or combined on modified atmosphere packaged chicken breast meat. International Journal of Food Microbiology, v.156, n.3, p.264-271, 2012. Available from: <https://doi.org/10.1016/j. ijfoodmicro.2012.04.002> Accessed: Mar. 3, 2018. doi: 10.1016/j. ijfoodmicro.2012.04.002.

RAMOS, E.M.; GOMIDE, L.A.M. Avaliação da qualidade de Carnes: fundamentos e metodologias. Viçosa: Editora UFV, 2007.

RENERRE, M.; LABADIE. J. Fresh red meat packaging and meat quality. In Proceedings 39th international congress of meat science and technology; Calgary, Canada, 1993. p. 361-387.

SAGOO, S. et al. Chitosan inhibits growth of spoilage microorganisms in chilled pork products. Food Microbiology, v.19, n.2-3, p.175- 182, 2002. Available from: <https://doi. org/10.1006/fmic.2001.0474>. Accessed: Nov. 15, 2017. doi: 10.1006/fmic.2001.0474.

SANTOS, P.R. et al. Tenderness and oxidative stability of Nellore bulls steaks packaged under vacuum or modified atmosphere during storage at $2{ }^{\circ} \mathrm{C}$. Food packaging and shelf life, v.4, p.10-18, 2015. Available from: <https://doi.org/10.1016/j.fpsl.2015.03.002>. Accessed: Mar. 25, 2018. doi: 10.1016/j.fps1.2015.03.002.

SIMÕES, J.A.; RICARDO, R. Avaliação da cor da carne tomando como referência o músculo rectus abdominis, em carcaças de cordeiros leves. Revista Portuguesa de Ciências Veterinárias, v.95, n.535, p.124-127, 2000.

SINCLAIR, L.A. Nutritional manipulation of the fatty acid composition of sheep meat: a review. Journal of Agricultural Science, v.145, n.5, p.419-434, 2007. Available from: $<$ https://doi. org $/ 10.1017 /$ S0021859607007186>. Accessed: Aug. 15, 2018. doi: $10.1017 / \mathrm{S} 0021859607007186$.

SNA - Sociedade Nacional de Agricultura. Produção de carne ovina pode ser mais rentável que bovina. 2015. Available from: $<$ http://www.sna.agr.br/producao-de-carne-ovina-pode-ser-maisrentavel-que-a-bovina/>. Accessed: Aug. 22, 2017.

SOBRINHO, A.G.S. et al. Meat Quality in Lambs of Different Genotypes and Ages at Slaughter. R. Bras. Zootec., v.34, n.3, p.1070-1078, 2005. Available from: <http://www.scielo.br/scielo. php?pid $=$ S1516-35982005000300040\&script $=$ sci arttext $>$. Accessed: Aug. 15, 2018. doi: 10.1590/S1516-35982005000300040.

ULIANA, M.P. et al. Composition and biological activity of Brazilian rose pepper (Schinus terebinthifolius Raddi) leaves. Industrial Crops and Products, v.83, p.235-240, 2016. Available from: <https://doi.org/10.1016/j.indcrop.2015.11.077>. Accessed: Mar. 26, 2018. doi: 10.1016/j.indcrop.2015.11.077.

VIECELLI, N.C. et al. Quantitative analysis of plasticizers in a wastewater treatment plant: influence of the suspended solids parameter. J. Braz. Chem. Soc., v.22, n.6, p.11501155, 2011. Available from: <http://dx.doi.org/10.1590/S010350532011000600021>. Accessed: Mar. 27, 2018. doi: 10.1590/ S0103-50532011000600021.

VIUDA-MARTOS, M. et al. Antioxidant activity of essential oils of five spice plants widely used in a Mediterranean diet. Flavour and Fragrance Journal, v.25, n.1, p.13-19, 2010. Available from: $<$ https://doi.org/10.1002/ffj.1951>. Accessed: Oct. 03, 2018. doi: 10.1002/ffj. 1951 
VYNCKE, B.W. Direct determination of the thiobarbituric acid value in trichloracetic acid extracts of fish as a measure of oxidative rancidity. Fette Seifen Anstrichmittel, Leinfelden-Echterdingen, v.72, n.12, p.1084-1087, 1970. Available from: <https://doi. org/10.1002/lipi.19700721218>. Accessed: Aug. 15, 2018. doi: 10.1002/lipi.19700721218.

VYNCKE, B.W. Evaluation of direct thiobarbituric acid extraction method for determining oxidative rancidity in mackerel (Scomber scombrus L.). Fette Seifen Anstrichmittel, LeinfeldenEchterdingen, v.72, p.239-240, 1975. Available from: <https:// doi.org/10.1002/lipi.19750770610>. Accessed: Aug. 15, 2018. doi: 10.1002/lipi.19750770610.

WASZKOWIAK, K. Antioxidative activity of rosemary extract using connective tissue proteins as carriers. International Journal of Food Science and Technology, v.43, n.8, p.1437-1442, 2008. Available from: <https://doi.org/10.1111/j.1365-2621.2007.01686. x>. Accessed: Aug. 15, 2018. doi: 10.1111/j.1365-2621.2007.01686.x.

ZAPATA, J.F.F. et al. Study on lamb quality from northeast brazil - physical and sensory properties. Ciência e Tecnologia de Alimentos, v.20, n.2, p.274-277, 2000. Available from: <http:// dx.doi.org/10.1590/S0101-20612000000200025>. Accessed: Nov. 20, 2017. doi: 10.1590/S0101-20612000000200025.

ZEOLA, N.M.B.L. et al. Colour, water holding capacity and tenderness of lamb aged and injected with calcium chloride. Arq. Bras. Med. Vet. Zootec., v.59, n.4, p.1058-1066, 2007. Available from: <http://dx.doi.org/10.1590/S010209352007000400036>. Accessed: Jun. 21, 2018. doi: 10.1590/ S0102-09352007000400036. 